\title{
RNF213/ALK Fusion Protein
}

National Cancer Institute

\section{Source}

National Cancer Institute. RNF213/ALK Fusion Protein. NCI Thesaurus. Code C99870.

A fusion protein ( $680 \mathrm{aa}, \sim 75 \mathrm{kDa}$ ) that is encoded by the RNF213/ALK fusion gene. This protein contains $1172 \mathrm{~N}$-terminal amino acids of protein ALO17 fused to the cytoplasmic domain of the ALK tyrosine kinase receptor protein. 